\title{
Gut microbiota and metabolic diseases: myth or reality?
}

\author{
Matteo Serino $\cdot$ Remy Burcelin
}

Received: 15 June 2010/ Accepted: 29 November 2010/Published online: 14 December 2010

(C) Springer-Verlag 2010

Microorganisms inhabiting human gastro-intestinal tract exceed the overall number of eukaryotic cells of about one order of magnitude [1-4]. Among the estimated 500-1,000 species [3], the majority has an unknown function, is neither beneficial nor harmful to host and represents the so-called "normal flora" or "microbiota" [5].

Noteworthy, the development of "next-generation" sequencing techniques, as part of the so-called "Omics", provided an holistic investigation allowing the study of the totality of gut microbiota, avoiding the need for lab-cultivation. These new molecular approaches opened the route toward a deeper investigation of the relationship between gut microbiota and host metabolism, focusing on multiple sides. Nowadays, Metagenomics [6, 7], Metatranscriptomics, Metabolomics [8] and Proteomics [9, 10] allow the study of gut microbiota genome, transcriptome and its impact on host metabolic profiles, respectively.

In the last decade, an increasing attention has been paid on gut microbiota, given its involvement in functions other than digestion, as the etiology of inflammatory bowel diseases [11-13], autoimmunity [14-16], allergy [17] and even cancer [2]. However, the inner relationship between gut microbiota and host metabolism has been extensively investigated especially focusing on metabolic diseases [5, 18], even if the molecular actors underlying this inner link are yet to be fully understood. Gordon's team performed

M. Serino $(\bowtie) \cdot R$. Burcelin

Institut National de la Santé et de la Recherche Médicale (INSERM), U858, Toulouse, France

e-mail: matteo.serino@inserm.fr

M. Serino $\cdot$ R. Burcelin

UPS, Institut de Médecine Moléculaire de Rangueil (I2MR), IFR150, Université de Toulouse, 31432 Toulouse Cedex 4, France pioneering studies using axenic (germfree) mice as a powerful model to study the impact of gut microbiota. Albeit these mice represent a non-physiologic model since the lack of gut microbiota impairs gut physiology [19], it has been shown that the establishment of a gut flora by colonization of axenic recipient mice with gut microbiota from donor mice is able to reverse this phenotype [20]. In addition, axenicity makes these mice resistant to dietinduced obesity, through a mechanism involving the enzyme lipoprotein lipase (LPL) and its inhibitor, the intestinal Fasting-induced adipocyte factor (Fiaf), which is over-activated in germfree conditions. This results in a diminished capacity to harvest energy from nutrients [21].

Gut microbiota ecology has been shown as deeply unbalanced in relation to metabolic diseases and on the top of it, obesity. The division of Firmicutes, a major phylum of gut microbiota in adulthood [22], has been positively correlated to body weight gain and obesity [23, 24]. Conversely, the division of Bacteroidetes, the second most represented phylum of gut bacterial ecology, characterizes a lean phenotype, both in humans and mice [23, 24]. Gordon's team was even the first to show the transmissibility of obesity by transferring its microbial component (gut microbiota issued from obese mice) into axenic recipient and showing an increased adipose tissue development when compared to recipient mice colonized with gut microbiota issued from lean mice [25].

However, metabolic diseases are always associated with a low-grade chronic inflammation in metabolically active tissues [26, 27]. Therefore, in the quest of a missing link between gut microbiota and inflammation, Burcelin's team was the first to link inflammation to intestinal microbiota and metabolic diseases by showing that an increase in lipopolysaccharides (LPS) plasma levels (referred to as "metabolic endotoxemia") was the initiator of metabolic 
diseases both in human [28] and mice [29]. Burcelin's research further demonstrated that a high-fat diet was responsible for gut microbiota ecology unbalance by decreasing the Gram positive bacteria count and, hence, by increasing the Gram negative to Gram positive ratio, leading to augmented endotoxemia [29]. Furthermore, using mice knock-out for the LPS receptor CD14 (part of the TLR-4 machinery of the innate immune system [30]), or continuously infusing subcutaneously low rates of LPS, we also provided a molecular evidence of the causal role of LPS in inducing metabolic diseases since CD14KO mice were protected from the metabolic effects of endotoxemia [29].

The demonstration of the causal role of gut microbiota within the etiology of metabolic diseases has led to the development of different strategies, i.e. the use of antibiotics, prebiotics and probiotics, aiming at impacting gut microbiota to ameliorate host metabolism. In detail, a chronic treatment of diabetic obese mice with antibiotics improved the glycemic control, by dramatically changing gut microbiota ecology [31, 32].

In the effort to modify gut microbiota ecology by enriching only bacteria that are beneficial for host metabolism, prebiotics [33] treatment has been shown to induce strong metabolic amelioration by reducing the inflammatory tone in diabetic mice, acting via an improved secretion of GLP-1 [34], a gut hormone which increases glucosestimulated insulin secretion $[35,36]$.

Furthermore, gut microbiota modification can even lead to improved drug metabolism as the case of some probiotics (live microorganisms) which have been shown capable to reduce glicazide bioavailability in healthy rats, whereas it increased in diabetic rats, leading to ameliorated glycemic control by insulin-independent mechanisms [37].

The studies reported above state the new role that gut microbiota is acquiring day-by-day as a profound modifier of host metabolism, meaning that gut microbiota is no longer considered as a passive actor of host physiology nor involved in digestive function only. For instance, shortchain fatty-acids, which represent the major product of polysaccharide fermentation by gut bacteria, have been shown to modulate host-adiposity by acting as ligands of the $\mathrm{G}$ protein-coupled receptor $\mathrm{Gpr} 41$, expressed by a special type of epithelial enteroendocrine cells of the gut [38]. Moreover, gut microbiota balance modification represents a metabolic switch that can address host status toward physiology or pathology as shown in human by analyzing gut bacterial ecology in lean and obese twins [39]. This study yielded to the identification of a core gut microbiome (a specific set of bacterial genes) that is shared among individuals with divergent gut microbiota, meaning that an organismal divergence in bacterial ecology can, however, yield to common functions. Nonetheless, deviations from this core have been associated with different metabolic state, i.e. lean compared to obesity [39].

Therefore, novel therapy can be developed to treat metabolic diseases and other pathologies such as allergy or cancer, for which gut microbiota modification represents an important and causative risk factor.

Conflict of interest None.

\section{References}

1. Bjorksten B, Sepp E, Julge K, Voor T, Mikelsaar M (2001) Allergy development and the intestinal microflora during the first year of life. J Allergy Clin Immunol 108:516-520

2. Guarner F, Malagelada JR (2003) Gut flora in health and disease. Lancet 361:512-519

3. Sears CL (2005) A dynamic partnership: celebrating our gut flora. Anaerobe 11:247-251

4. Steinhoff U (2005) Who controls the crowd? New findings and old questions about the intestinal microflora. Immunol Lett 99:12-16

5. Serino M, Luche E, Chabo C, Amar J, Burcelin R (2009) Intestinal microflora and metabolic diseases. Diabetes Metab 35: 262-272

6. Handelsman J, Rondon MR, Brady SF, Clardy J, Goodman RM (1998) Molecular biological access to the chemistry of unknown soil microbes: a new frontier for natural products. Chem Biol 5:R245-R249

7. Chen K, Pachter L (2005) Bioinformatics for whole-genome shotgun sequencing of microbial communities. PLoS Comput Biol 1:106-112

8. Nicholson JK (2006) Global systems biology, personalized medicine and molecular epidemiology. Mol Syst Biol 2:52

9. Anderson NL, Anderson NG (1998) Proteome and proteomics: new technologies, new concepts, and new words. Electrophoresis 19:1853-1861

10. Blackstock WP, Weir MP (1999) Proteomics: quantitative and physical mapping of cellular proteins. Trends Biotechnol 17:121-127

11. Swidsinski A, Ladhoff A, Pernthaler A, Swidsinski S, LoeningBaucke V, Ortner M, Weber J, Hoffmann U, Schreiber S, Dietel M, Lochs H (2002) Mucosal flora in inflammatory bowel disease. Gastroenterology 122:44-54

12. Shanahan F (2005) Physiological basis for novel drug therapies used to treat the inflammatory bowel diseases I. Pathophysiological basis and prospects for probiotic therapy in inflammatory bowel disease. Am J Physiol Gastrointest Liver Physiol 288:G417-G421

13. Sokol H, Pigneur B, Watterlot L, Lakhdari O, Bermudez-Humaran LG, Gratadoux JJ, Blugeon S, Bridonneau C, Furet JP, Corthier G, Grangette C, Vasquez N, Pochart P, Trugnan G, Thomas G, Blottiere HM, Dore J, Marteau P, Seksik P, Langella P (2008) Faecalibacterium prausnitzii is an anti-inflammatory commensal bacterium identified by gut microbiota analysis of Crohn disease patients. Proc Natl Acad Sci USA 105:16731-16736

14. Macpherson AJ, Harris NL (2004) Interactions between commensal intestinal bacteria and the immune system. Nat Rev Immunol 4:478-485

15. Rakoff-Nahoum S, Medzhitov R (2006) Role of the innate immune system and host-commensal mutualism. Curr Top Microbiol Immunol 308:1-18

16. Ivanov II, Atarashi K, Manel N, Brodie EL, Shima T, Karaoz U, Wei D, Goldfarb KC, Santee CA, Lynch SV, Tanoue T, Imaoka 
A, Itoh K, Takeda K, Umesaki Y, Honda K, Littman DR (2009) Induction of intestinal Th17 cells by segmented filamentous bacteria. Cell 139:485-498

17. Macdonald TT, Monteleone G (2005) Immunity, inflammation, and allergy in the gut. Science 307:1920-1925

18. Burcelin R, Luche E, Serino M, Amar J (2009) The gut microbiota ecology: a new opportunity for the treatment of metabolic diseases? Front Biosci 14:5107-5117

19. Shanahan F (2002) The host-microbe interface within the gut. Best Pract Res Clin Gastroenterol 16:915-931

20. Umesaki Y, Okada Y, Matsumoto S, Imaoka A, Setoyama H (1995) Segmented filamentous bacteria are indigenous intestinal bacteria that activate intraepithelial lymphocytes and induce MHC class II molecules and fucosyl asialo GM1 glycolipids on the small intestinal epithelial cells in the ex-germ-free mouse. Microbiol Immunol 39:555-562

21. Backhed F, Manchester JK, Semenkovich CF, Gordon JI (2007) Mechanisms underlying the resistance to diet-induced obesity in germ-free mice. Proc Natl Acad Sci USA 104:979-984

22. Reinhardt C, Reigstad CS, Backhed F (2009) Intestinal microbiota during infancy and its implications for obesity. J Pediatr Gastroenterol Nutr 48:249-256

23. Ley RE, Backhed F, Turnbaugh P, Lozupone CA, Knight RD, Gordon JI (2005) Obesity alters gut microbial ecology. Proc Natl Acad Sci USA 102:11070-11075

24. Ley RE, Turnbaugh PJ, Klein S, Gordon JI (2006) Microbial ecology: human gut microbes associated with obesity. Nature 444:1022-1023

25. Turnbaugh PJ, Ley RE, Mahowald MA, Magrini V, Mardis ER, Gordon JI (2006) An obesity-associated gut microbiome with increased capacity for energy harvest. Nature 444:1027-1031

26. Dandona P, Aljada A, Bandyopadhyay A (2004) Inflammation: the link between insulin resistance, obesity and diabetes. Trends Immunol 25:4-7

27. Wellen KE, Hotamisligil GS (2005) Inflammation, stress, and diabetes. J Clin Invest 115:1111-1119

28. Amar J, Burcelin R, Ruidavets JB, Cani PD, Fauvel J, Alessi MC, Chamontin B, Ferrieres J (2008) Energy intake is associated with endotoxemia in apparently healthy men. Am J Clin Nutr 87:1219-1223
29. Cani PD, Amar J, Iglesias MA, Poggi M, Knauf C, Bastelica D, Neyrinck AM, Fava F, Tuohy KM, Chabo C, Waget A, Delmee E, Cousin B, Sulpice T, Chamontin B, Ferrieres J, Tanti JF, Gibson GR, Casteilla L, Delzenne NM, Alessi MC, Burcelin R (2007) Metabolic endotoxemia initiates obesity and insulin resistance. Diabetes 56:1761-1772

30. Aderem A, Ulevitch RJ (2000) Toll-like receptors in the induction of the innate immune response. Nature 406:782-787

31. Cani PD, Bibiloni R, Knauf C, Waget A, Neyrinck AM, Delzenne NM, Burcelin R (2008) Changes in gut microbiota control metabolic endotoxemia-induced inflammation in high-fat dietinduced obesity and diabetes in mice. Diabetes 57:1470-1481

32. Membrez M, Blancher F, Jaquet M, Bibiloni R, Cani PD, Burcelin RG, Corthesy I, Mace K, Chou CJ (2008) Gut microbiota modulation with norfloxacin and ampicillin enhances glucose tolerance in mice. Faseb J 22:2416-2426

33. Gibson GR, Roberfroid MB (1995) Dietary modulation of the human colonic microbiota: introducing the concept of prebiotics. J Nutr 125:1401-1412

34. Cani PD, Daubioul CA, Reusens B, Remacle C, Catillon G, Delzenne NM (2005) Involvement of endogenous glucagon-like peptide-1(7-36) amide on glycaemia-lowering effect of oligofructose in streptozotocin-treated rats. J Endocrinol 185:457-465

35. Burcelin R (2005) The incretins: a link between nutrients and well-being. Br J Nutr 93(Suppl 1):S147-S156

36. Holst JJ (2007) The physiology of glucagon-like peptide 1 . Physiol Rev 87:1409-1439

37. Al-Salami H, Butt G, Fawcett JP, Tucker IG, Golocorbin-Kon S, Mikov M (2008) Probiotic treatment reduces blood glucose levels and increases systemic absorption of gliclazide in diabetic rats. Eur J Drug Metab Pharmacokinet 33:101-106

38. Samuel BS, Shaito A, Motoike T, Rey FE, Backhed F, Manchester JK, Hammer RE, Williams SC, Crowley J, Yanagisawa M, Gordon JI (2008) Effects of the gut microbiota on host adiposity are modulated by the short-chain fatty-acid binding $G$ protein-coupled receptor, Gpr41. Proc Natl Acad Sci USA 105:16767-16772

39. Turnbaugh PJ, Hamady M, Yatsunenko T, Cantarel BL, Duncan A, Ley RE, Sogin ML, Jones WJ, Roe BA, Affourtit JP, Egholm M, Henrissat B, Heath AC, Knight R, Gordon JI (2009) A core gut microbiome in obese and lean twins. Nature 457:480-484 